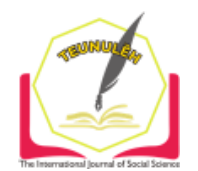

Jurnal Ilmiah Teunuleh

The International Journal of Social Sciences

Vol. 1, Issue. 2, Dec 2020

E-ISSN: 2746-4393

\title{
THE INFLUENCE OF DISCOVERY LEARNING MODELS AND SOLVING SKILLS PROBLEMS WITH PPKn LEARNING OUTCOMES GRADE 4 STUDENTS AT SD KATOLIK DISKI
}

\author{
Putri Melly Andani Marbun ${ }^{1}$ \\ Deny Setiawan ${ }^{2}$ \\ Asih Menanti ${ }^{3}$ \\ ${ }^{123}$ Universitas Negeri Medan \\ ${ }^{1}$ putrimarbun@gmail.com
}

\begin{abstract}
This research is motivated by the purpose of education to obtain good learning outcomes. Such success depends on internal and external factors, as one part of the internal factor is problem solving skills. The existence of problem-solving skills students can more easily overcome problems encountered when learning or designed by teachers. The purpose of this study was to find out the comparison of students' PPKn learning outcomes between the Discovery Learning model and the Think Pair and Share model, also to find out the comparison of PPKn learning outcomes of students who have high problem solving skills with students who have low problem solving skills, and also to know the interaction between the learning model and problem solving skills to the learning outcomes of PPKn students in grade IV of Diski Catholic Elementary School. This study using quantitative approach with the results of the study showed that the results of ppkn students with Discovery Learning model is higher than the learning results of PPKn students with Think Pair and Share model, evidenced from $Q_{\text {hitung }}>Q_{\text {tabel }}$ (4.34 > 2.81; with a level of 5\%). PPKn learning outcomes of students who have high problemsolving skills are higher than ppkn learning outcomes of students who have low problem-solving skills, as evidenced by $Q_{\text {hitung }}>Q_{\text {tabel }}(3.03>2.81$; with a level of 5\%). There is an interaction between learning models and problem-solving skills to students' PPKn learning outcomes, as evidenced by $F_{\text {hitung }}>F_{\text {tabel }}$ which is $8.59>4.20$. The conclusion of this study explains that the learning outcomes of students who have high and low skills are more suitable to be taught with discovery learning models than students who are taught using the Think Pair Share model.
\end{abstract}

Keywords: Discovery Learning Models, Troubleshooting Skills, Learning Outcomes

A. Introduction 
Students' success in achieving learning outcomes varies. The factors that influence student success in achieving learning outcomes are grouped into two, namely internal factors and external factors. Internal factors are factors that come from within students, including student physiological (physical) factors and psychological factors including students' intelligence (intelligence), problem solving skills, interests, attitudes, and talents. External factors are factors from outside of students, including natural and socio-cultural environments, non-social or instrumental environments, namely curricula, programs, learning facilities, teachers (Kompri, 2016). PPKn learning outcomes are indicated by the achievements obtained by students. This achievement is in the form of values obtained when children participate in the learning process in class.

The results of interviews with PPKn subject teachers, obtained information about the results of odd semester examinations in PPKn subjects for the 2018/2019 learning year at the Diski Catholic Private SD. From these results there are still quite a lot of students whose scores are below the Minimum Completeness Criteria (KKM). Percentage data from two (2) grade IV SD Katolik Diski are presented in Table 1.1.

Student ythose who are still under the KKM are given a remedy. From the results of a survey conducted by researchers in January 2019, remedies for students whose grades were still insufficient were only given questions without providing learning material to students who did not understand or master the competencies that had been given. It is better if the implementation of remedies is not only re-examining, but also re-learning, so that competencies that are not understood by students will be well understood. The implementation of remedies requires additional time and will add a new problem when the implementation of the semester schedule ends and changes to the next semester, and teachers are required to immediately complete teaching administration.

The researcher chose to use a learning model discovery learning For PPKn learning the theme of the beauty of togetherness in grade IV because in this material students are taught how diversity and differences with the people around them can keep togetherness and can avoid conflicts and disputes that may arise, with the discovery learning model (Discovery Learning), students are expected to be able to find solutions to problems that occur. 
The Influence of Discovery Learning Models and Solving Skills Problems...

Table 1.1. Percentage of Odd Semester Test Values for Class IV PPKn Subjects in Private Catholic SD Diski Academic Year 2019/2020

\begin{tabular}{|c|c|c|}
\hline Class & $\geq$ KKM & $<$ KKM \\
\hline IV-A & $40 \%$ & $60 \%$ \\
\hline IV-B & $30 \%$ & $70 \%$ \\
\hline
\end{tabular}

General PPKn learning in grades IV-A and VI-Bnot optimal, it can be seen from the learning outcomes of many students who are still below the KKM. This requires the provision of a learning model so that learning problem solving skills and student learning outcomes increase.

\section{B. Method}

This research was conducted in fourth grade private Catholic SD Deli Murni Diski which is located on Jalan Binjai Km 14.5, Deli Serdang Regency, North Sumatra. The reason for carrying out research in this school is because of the discovery of learning that still uses a teacher centered learning model and the achievement of student learning outcomes under the KKM.

This research will be carried out for 2 months in the odd semester of the 2020/2021 school year, starting from July to August 2020. The subject matter chosen in this study is "Beautiful Togetherness" which is the 1st theme in grade IV which is currently being studied in that semester.

Population is the set of all characteristics of the object under study (Mahmud 2011: 154). The population in this study were all class IV students of the Catholic Private SD Diski, totaling 56 people, with details

a. Class IV-A: 28 person

b. Class IV-B : 28 people

This type of research is a quasi experiment (pseudo-experiment), which aims to see the effect of independent variables on the dependent variable, and to determine whether there is an effect on the subject, namely students.

The research design used was a two group pretest-posttest design. This design is the most effective in terms of showing a cause and effect relationship. This study involved two classes, namely the control class and the experimental class which were given different treatments. In the experimental class treated with Discovery Learning 
learning model, and in the control class treated with Think Pair and Share learning model

\section{Finding and Discussion}

\section{Student PPKn Learning Outcomes Data Taught Using ModelsDiscovery Learning (A1)}

Based on the data obtained from the results of the PPKn learning pretest students who are taught using the Discovery Learning learning model in attachment 5 and the frequency distribution data in attachment 6 can be described as follows: the student average score was 33.25; Variance = 79.08; Standard Deviation $(S D)=8.89$; maximum value $=50$; Minimum value $=17$, with a range of values (Range) $=33$. While the data obtained from the results of the PPKn learning posttest of students who were taught using the Discovery Learning learning model can be described as follows: 75; Variance $=71.3$; Standard Deviation $(S D)=8.44$; maximum value $=93$; Minimum value $=57$, with a range of values (Range) $=36$.

The pretest data assessment categoryPPKn learning outcomes of students who have high problem solving skills are taught using the Discovery Learning learning modelcan be seen in the following table:

Table 2.1. Categories of Pre-Test Assessment of Student Learning Outcomes Teaching Using Models Discovery Learning (A1)

\begin{tabular}{|c|c|c|c|c|}
\hline No. & Value Interval & $\begin{array}{c}\text { The number } \\
\text { of students }\end{array}$ & Percentage & Rating Category \\
\hline 1 & $0 \leq \mathrm{SHB}<45$ & 24 & $85.71 \%$ & Very less \\
\hline 2 & $45 \leq \mathrm{SHB}<65$ & 4 & $14.29 \%$ & Less \\
\hline 3 & $65 \leq \mathrm{SHB}<75$ & 0 & $0.00 \%$ & Enough \\
\hline 4 & $75 \leq \mathrm{SHB}<90$ & 0 & $0.00 \%$ & Good \\
\hline 5 & $90 \leq \mathrm{SHB} \leq 100$ & 0 & $0.00 \%$ & Very good \\
\hline
\end{tabular}

Information: $\mathrm{SHB}=$ Score of Learning Outcomes

From the table above, the PPKn learning outcomes of students who were taught with the Discovery Learning learning model found that: there were 24 students or $85.71 \%$ of students were in the very poor category. There are 4 people or $14.29 \%$ in the less category. There are no students who are categorized as sufficient, good and very good from the learning outcomes of students who are taught using the Discovery Learning learning model. With mean $=33.25$ then the average PPKn learning outcomes 
The Influence of Discovery Learning Models and Solving Skills Problems...

of students taught using the Discovery Learning learning model are categorized as Very Less.

While the post-test data assessment category PPKn learning outcomes of students who have high problem solving skills are taught using the Discovery Learning learning modelcan be seen in the following table:

Table 2.2. Categories of Post-Test Assessment of Students' PPKn Learning Results Taught Using a ModelDiscovery Learning (A1)

\begin{tabular}{|c|c|c|c|c|}
\hline No. & Value Interval & $\begin{array}{c}\text { The number } \\
\text { of students }\end{array}$ & Percentage & Rating Category \\
\hline 1 & $0 \leq \mathrm{SHB}<45$ & 0 & $0.00 \%$ & Very less \\
\hline 2 & $45 \leq \mathrm{SHB}<65$ & 3 & $10.71 \%$ & Less \\
\hline 3 & $65 \leq \mathrm{SHB}<75$ & 11 & $39.29 \%$ & Enough \\
\hline 4 & $75 \leq \mathrm{SHB}<90$ & 12 & $42.86 \%$ & Good \\
\hline 5 & $90 \leq \mathrm{SHB} \leq 100$ & 2 & $7.14 \%$ & Very good \\
\hline
\end{tabular}

Information: $\mathrm{SHB}=$ Score of Learning Outcomes

From the table above, the PPKn learning outcomes of students who were taught with the Discovery Learning learning model found that: there were no students or $0 \%$ was in the very poor category. There are 3 people or $10.71 \%$ in the less category. There are 11 students or $39.29 \%$ in the sufficient category. There are 12 students or $42.86 \%$ in either category. There are 2 students or $7.14 \%$ including the very good category of student learning outcomes taught using the Discovery Learning learning model. With mean $=75$ then the average PPKn learning outcomes of students taught using the Discovery Learning learning model are categorized as Good.

\section{Student PPKn Learning Outcomes Data Taught Using the Think Pair Share (A2) Learning Model}

Based on the data obtained from the results of the PPKn learning pretest students taught using the Think Pair Share learning model in appendix 5 and the frequency distribution data in attachment 6 can be described as follows: the student's average score was 30.57; Variance $=70.92$; Standard Deviation $(S D)=8.42$; maximum value $=47$; The minimum value $=10$, with a range of values (Range) $=37$. While the data obtained from the PPKn learning post-test results of students who are taught using the Think Pair Share learning model can be described as follows: 68.57; Variance $=101.66$; Standard Deviation $(S D)=10.08$; maximum value $=87$; Minimum value $=37$, with a range of values (Range) $=50$. 
Table 2.3. Pretest and Posttest Data for Experiment Class II (A2)

\begin{tabular}{|c|l|c|c|}
\hline \multirow{2}{*}{ No. } & \multirow{2}{*}{ Statistics } & \multicolumn{2}{|c|}{ Experiment II } \\
\cline { 3 - 4 } & & Pretest & Postes \\
\hline 1 & $\mathrm{~N}$ & 28 & 28 \\
\hline 2 & Total Value & 856 & 1920 \\
\hline 3 & Average & 30.57 & 68.57 \\
\hline 4 & Standard Deviation & 8.421 & 10.083 \\
\hline 5 & Variance & 70.92 & 101.66 \\
\hline 6 & Maximum & 47 & 87 \\
\hline 7 & Minimum & 10 & 37 \\
\hline
\end{tabular}

The meaning of the above variant results is PPKn learning outcomes of students taught with the Think Pair Share learning model have various or different values from one student to another, because we can see that the variance value exceeds the highest value from the data above.

The findings of the hypothesis provide the conclusion that:

1. Student PPKn learning outcomes taught with the Discovery Learning model were higher than those taught using the Think Pair and Share model.

This is in accordance with Bruner's statement (Journal, 2018: 18). Learning through discovery (Discovery Learning) has a good learning concept. The purpose of discovery learning strategies is to provide opportunities for students to become problem solvers, scientists and historians. Therefore, to achieve their personal goals, group members must help their teammates to do whatever it takes to make their group successful, and perhaps more importantly, encourage the members of one group to put forth their maximum effort. In other words, Group rewards that are based on group performance (or the sum of individual performance) create an interpersonal reward structure in which group members will provide or block social triggers (such as praise and encouragement) in response to efforts related to group assignments. Thus, between one student and another student in the group can provide the answer in their own way. Without realizing it, students have been doing creative thinking activities, because each student will try to answer questions in a different way from his friends, besides that they also pay attention to the quality of the answers given. This is also proven by the research of Firosalia Kristin. 
The Influence of Discovery Learning Models and Solving Skills Problems...

2. The PPKn learning outcomes of students who have high problem solving skills are higher than the PPKn learning outcomes of students who have low problem solving skills.

This is in accordance with what Ilahi (2016: 184) stated that problem solving skills are one of the implications of applying discovery. Because, this ability indicates that students are able to think solutions in dealing with various problems at hand. This also relates to the student's ability to strive for conveniences that make all difficulties encountered when discovery learning takes place can be solved together. In other words, problem solving skills are able to influence learning outcomes for each student.

3. There is an interaction between the learning model and problem-solving skills on student PPKn learning outcomes.

As previously discussed in the background of the problem, the strategies used in the teaching and learning process have an effect in determining student learning outcomes. Which in this case is the Discovery Learning learning model. With the varied learning given to students, students' high problem solving skills can be formed and pushed out. Besides the activities and creativity that are expected in a learning process that requires balanced interaction, the intended interaction is the interaction or communication between students and students and between students and teachers.

In the learning process, it is hoped that there will be many directions of communication that allow the expected activities and creativity to occur. This of course depends on the learning strategies used, because the strategies used will help show the intended learning outcomes. In addition, the learning strategy determines whether students can interact with students only or between students and teachers.

As explained above, creativity will be created if there is communication in many directions, namely between students and teachers and also between students and students. In this case, the selection of the Discovery Learning learning model can help students to communicate in many directions, with the Discovery Learning learning model students will interact in groups. Thus this proves that the learning model given to students interacts with problem solving skills on student learning outcomes.

\section{CONCLUSION}

Based on the research results that have been obtained, as well as the problems that have been formulated, the authors make the following conclusions: 
1. Students' PPKn learning outcomes taught with the Discovery Learning model were higher than those taught with the Think Pair and Share model in grade IV of SD Katolik Diski.

2. The PPKn learning outcomes of students who have high problem solving skills are higher than the PPKn learning outcomes of students who have low problem solving skillsin grade IV of Diski Catholic Elementary School.

3. There is an interaction between the learning model and problem-solving skills on student PPKn learning outcomes in grade IV SD Katolik Diski.

\section{Bibliography}

Anisa, Nur Ewid dan Ratu. (2017). Pembelajaran Discovery Learning Untuk Meningkatkan Motivasi Belajar dan Penguasaan Konsep Siswa. Jurnal Pendidikan dan Pembelajaran Kimia. 6 (2). 283-295. Agustus 2017

Anzar, S. F., \& Mardhatillah, M. (2018). Analisis Kesulitan Belajar Siswa Pada Pembelajaran Bahasa Indonesia di Kelas V SD Negeri 20 Meulaboh Kabupaten Aceh Barat Tahun Ajaran 2015/2016. Bina Gogik: Jurnal Ilmiah Pendidikan Guru Sekolah Dasar, 4(1).

Arends, R. (2008). Learning to Teach (7th ed.) Belajar untuk Mengajar (Terjemahan Helly Prajitno Soetjipto dan Sri Mulyantini Soetjipto pada Tahun 2008). Yogyakarta: Pustaka Pelajar.

Bejo. (2017). Peningkatan Kemampuan Pemecahan Masalah HAM Melalui Model Problem Based Learning Pada Siswa Kelas VI SDN 0713 Pir Trans Sosa I A. Jurnal IImu Pengetahuan Sosial. 1. 26-31. Januari 2017

Bachri, Syaiful, (2003). Strategi Belajar Mengajar. Jakarta: Rineka Cipta

Deti Rostika dan Herni Junita. (2017). Peningkatan Kemampuan Pemecahan Masalah Siswa SD Dalam Pembelajaran Matematika Dengan Model Diskursus Multy Representation (DMR). Jurnal Pendidikan Dasar. 9 (1). 35-46. Januari 2017

Dahar, Ratna Wilis. (2006). Teori-teori Belajar \& Pembelajaran. Jakarta : Erlangga

Laksana, Sigit Dwi. (2018). Implementasi Model Discovery Learning Dalam Meningkatkan Prestasi Belajar Siswa Kelas IV Madrasah Ibtidaiah (MI) Al-Ma' arif Gendingan Kec. Kedungwaru Kab. Tulungagung. Jurnal IImiah PGMI. 4 (1). Juni 2018

Mahmud. (2011). Metode Penelitian Pendidikan. Bandung: Pustaka Setia

Mardenis. (2016). Pendidikan Kewarganegaraan Dalam Rangka Pengembangan Kepribadian Bangsa. Padang: PT. Raja Grafindo Persada 
The Influence of Discovery Learning Models and Solving Skills Problems...

Mulyasa. (2016). Pengembangan dan Implementasi Kurikulum 2013. Bandung : Rosda Nurgazali, Fadhlan. (2019). Model Discovery Learning Dalam Pembelajaran Matematika. Jurnal Pascasarjana Unimed. 2019

Purwanto. (2008). Evaluasi Hasil Belajar. Surakarta : Pustaka Belajar

Rasmiyati. (2016). Upaya Meningkatkan Prestasi Belajar PKN Melalui Metode Discovery Learning Pada Siswa Kelas III SDN Kamal 2 Kecamatan Kamal Kabupaten Bangkalan Tahun Pelajaran 2015/2016. Jurnal Widyagogik. 3 (2). 11-20. Juni 2016

Ridwan. (2017). Pembelajaran Saintifik untuk Implementasi Kurikulum 2013. Jakarta : Bumi Aksara

Sabekti, Kharisma dan Angela. (2017). Penerapan Metode Discovery Learning Untuk Meningkatkan Keaktifan Belajar Siswa Pada Mata Pelajaran Teknologi Informasi dan Komunikasi (Studi di SMA Negeri 1 Suruh). Jurnal FTI Univ Kristen Satya Wacana. 1-16. 2017

Sadulloh, Uyoh. (2018). Pedagogik IImu Mendidik. Bandung: Alfabeta

Sanjaya, Wina. (2011). Strategi Pembelajaran Berorientasi Standar Proses Pendidikan. Jakarta: Kencana

Setiawan, Deny. (2016). Pendidikan Kewarganegaraan. Medan : Madenatera

Setiawan, Deny. (2015). Ilmu Kewarganegaraan. Medan: Larispa

Sirait, Maruslin. (2017). Model Pembelajaran Berbasis Discovery-Inkuiri dan Kontribusinya Terhadap Penguatan Kualitas Pembelajaran di Sekolah Dasar. Jurnal Pendidikan Dasar. 1 (2). 155-170. 2017

Slameto. (2013). Belajar dan Faktor-faktor Yang Mempengaruhi. Jakarta : Rineka Cipta

Sumantri, Bambang. (2014). Peningkatan Kualitas Pembelajaran PKn Melalui Model Pembelajaran Kooperatif Tipe Teams Game Tournamen (TGT) Pada Siswa Kelas III SDN Pelem 2 Ngawi. Jurnal IImiah STKIP PGRI Ngawi. 13 (1). 20-30. 2014

Sumiati \& Asra. (2018). Metode Pembelajaran. Bandung : CV Wacana Prima

Takdir Ilahi, Mohammad. 2016. Pembelajaran Discovery Strategi dan Mental Vocational Skill. Yogyakarta: Diva Press

Trianto, (2009). Mendesain Model Pembelajaran Inovatif-Progresif. Jakarta:Kencana

Winda, Melda. (2014). Peningkatan Keaktifan Siswa Melalui Penerapan Metode Discovery Dalam Pembelajaran PKn di Kelas X SMAN 2 Lengayang Pesisir Selatan. Jurnal Tingkap. 10 (1). 43-57. 2014

Wirdaningsih, W., \& Mardhatillah, M. (2016). Penerapan Media Audio-Visual Terhadap Keaktifan Pada Materi Hubungan Antara Sumber Daya Alam Dengan Lingkungan Siswa Kelas IV SD Negeri Pasi Teungoh Kecamatan Kaway XVI. Bina Gogik: Jurnal IImiah Pendidikan Guru Sekolah Dasar, 3(2). 